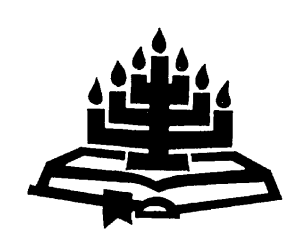

\title{
Vorming van 'n man van God: evaluering van internasionale debatte oor predikantsopleiding in die lig van perspektiewe uit 1 en 2 Timoteus
}

\author{
P.J. Buys \\ Skool vir Kerkwetenskappe \\ Potchefstroomkampus \\ Noordwes-Universiteit \\ POTCHEFSTROOM \\ E-pos: flip@mukhanyo.co.za
}

\begin{abstract}
Moulding of a man of God: an evaluation of international debates on pastoral training in the light of perspectives from 1 and 2 Timothy

During the past 50 years a wide variety of discussions, reflections and debates on theological education has been published. These debates and reflections were stimulated by the following factors: On the one hand there is an explosion of church growth in developing countries. On the other hand there is an alarming decline in church growth in developed countries. There is also deep concern about the lack of impact of churches on the transformation of communities. Church leaders are often not succeeding in stimulating and equipping believers to be effective witnesses in the world. These factors have given rise to the question: How should theological education be restructured to become a vital factor that leads to spiritual growth as well as growth in numbers of churches? Serious questions about the godliness and spirituality of church leaders, of pastors and seminary students are raised. This article evaluates international tendencies in the light of principles and perspectives from Paul's epistles to Timothy.
\end{abstract}




\section{Opsomming}

\section{Vorming van 'n man van God: evaluering van internasionale debatte oor predikantsopleiding in die lig van perspektiewe uit 1 en 2 Timoteus}

Die afgelope 50 jaar word wêreldwyd breed en diep oor teologiese opleiding besin. Hierdie besinning is deur die volgende faktore gestimuleer: Aan die een kant is daar in ontwikkelende lande 'n ontploffende getallegroei van kerke. Aan die ander kant is daar in ontwikkelde lande kommerwekkende kwynende lidmaatgetale. Daar is ook kommer dat kerke weinig impak op transformasie van die samelewing het. Voorgangers slaag dikwels nie in hulle voorbeeld en bediening daarin om instrumente in God se hand te wees wat gelowiges toerus en inspireer om werklik getuies van Christus te wees nie. Hierdie verskynsels het gelei tot die vraag: Hoe kan en moet teologiese opleiding van kerklike voorgangers herstruktureer word ten einde kerke effektief geestelik en in getalle te laat groei? In hierdie verband is daar ernstige vrae gevra oor die godsvrug en persoonlike geloofslewe van predikante en teologiese studente. Hierdie artikel evalueer internasionale tendense en debatte in teologiese opleiding in die lig van beginsels en perspektiewe wat uit Paulus se briewe aan Timoteus afgelei kan word.

\section{Inleiding: wye internasionale besinning oor predikantsopleiding}

Wanneer 'n mens bolangs die diskussies in teologiese en kerklike publikasies en selfs die gewone dagbladpers volg, is dit duidelik dat daar die afgelope vyf dekades steeds wyer en indringender opnuut besin en gepubliseer word oor teologiese opleiding (Cole, 2001:215; 2007:171; Ferris, 2001; Eliston, 1999; Haak, 1999; Hart \& Mohler, 1996; Bosch, 1984; Woods, 1995; Wells, 1994; Kornfield, 1984: 169-221; Newbigin 1984:3-18; Conn, 1979:311-363; De Villiers, 1976; Schrotenboer, 1976:6-8; Covell \& Wagner, 1971).

In Maart 2003 is 'n hele uitgawe van Mission frontiers gewy aan verskillende knelpunte in predikantsopleiding (Winter, 2003:10, 11).

Wells (1994:25) maak onstellende stellings ontleen aan 'n navorsingsprojek, dat baie teologiese studente wat kognitief hulle teologiese oortuigings bely, dit nie werklik beleef en in hulle alledaagse lewe uitleef nie. Piper (1999:20) meen dat die tendens dat baie teologiese studieprogramme Spiritualiteit as 'n ekstra vak tot kurrikula toevoeg 'n hoopvolle teken is, maar tegelyk ook 'n aanduiding is van 'n kommerwekkende leemte. Die leemte is dat die hele spek- 
trum van teologiese opleiding faal om in elke vakgebied die mees kardinale uitkoms van teologiese opleiding te bereik. Die uitkoms is naamlik dat dosent, predikant en sendeling se grootste nood is om God self in al sy majesteit, soewereiniteit en heerlikheid beter te ken as wat hulle enigiets anders ken. Ook om groter vreugde in Hom te vind as in enigiets anders.

Omdat dit volgens hom in Sistematiese Teologie, Bibliologiese en Praktiese Teologiese vakke gemis word, word daar 'n poging aangewend om tog daaraan aandag te gee deur ekstra vakgebiede soos Spritualiteit of Geestelike vorming tot die kurrikula toe te voeg. Dit dui op 'n kritieke breuk tussen leer en lewe. Dit is bevindings wat teologiese opvoeders behoort te ontstel en hulle indringend te laat herbesin oor die versoening van godsvrug en Bybelse vroomheid met intellek en praktiese bedieningsvaardighede (vgl. Farley, 1983: 11).

Behalwe die vele publikasies het verskillende organisasies soos teologiese akkreditasie organisasies, byvoorbeeld International Council for Accrediting Agencies (hierna ICAA) sedert 1980, na baie wye internasionale konsultasie, manifeste uitgereik waarin dringend gevra word vir herbesinning, vernuwing en verbetering van teologiese opleiding.

In die laat tagtigerjare het Ferris (vgl. Cole, 2001:13) wêreldwyd 'n opname gemaak van 242 instellings wat hulle akkreditasie deur hierdie organisasies ontvang het. Sy bevindings het ingesluit dat 'n oorweldigende meerderheid van hierdie instellings dringend gevra het vir radikale vernuwing van die inhoud (kurrikula), diversiteit, sowel as die wyse van opleiding, maar dat $85 \%$ van die hoofde van die instellings wat ondersoek is, nie bewus was van die bestaan van ICAA se manifes nie en ook nie dat die meeste van hulle versoeke daarin opgeneem was nie.

Die konsultasie oor Institutional Development for Theological Education in the Two-thirds World wat in 1995 by die Oxford Sendingsentrum plaasgevind het, is ook van groot belang. 'n Groot aantal hoofde van teologiese opleidingsinstellings in Westerse sowel as nie-Westerse lande het besin oor 'n wye veld van tersaaklike onderwerpe. Dit het gegaan oor die historiese ontwikkeling van teologiese opleiding, oor tegnologie en navorsing, oor kurrikulumontwikkeling en die handhawing van standaarde en akkreditasie, oor die vestiging en volhoubare ekonomie en goeie bestuur van instellings, en so meer (vgl. Cole, 2001:15, 16). 
In 1999 het 80 opleidingsinstansies uit 50 lande van die wêreld 'n konsultasie oor die kritieke nood aan predikantsopleiding in die ontwikkelende wêreld in Manilla gereël. Dit het uitgeloop op die vorming van TOPIC (Training of Pastors International Coalition). TOPIC wil 'n internasionale netwerkorganisasie wees wat samewerking tussen opleidingsinstansies fasiliteer om die opleiding van drie miljoen onopgeleide predikante in ontwikkelende lande te versnel en te vermenigvuldig (Landrey, 2009; Buys, 1999.)

Die Asiëstreek van World Reformed Fellowship het in April 2009 'n konferensie in Jakarta oor die nood van relevante teologiese opleiding gereël, wat deur ongeveer 70 afgevaardigdes uit Sjina, Hong Kong, Taiwan, Indië, Sri Lanka, Singapoer, Korea, Mianmar, Nepal en die Filippyne bygewoon is. Enkele sprekers uit Skotland, die VSA en Suid-Afrika het dit ook bygewoon. In die bespreking van 'n aanbieding oor Die werk van die Heilige Gees in holistiese in-diens-opleidingsmodelle van predikante in ontwikkelende lande (Buys, 1999) was daar verbasend instemmende belangstelling en reaksies wat na ' $n$ algehele herevaluering van predikantsopleiding roep.

Slegs 'n oorsig van al die publikasies, konsultasies en internasionale vergaderings oor teologiese opleiding is al genoeg om 'n boek oor te skryf en dit is beslis nie die doel van hierdie artikel nie. Hoogstens kan sekere tendense wat telkens in die diskussies en debatte voorkom, uitgelig en geëvalueer word in die lig van beginsels wat uit Paulus se briewe aan Timoteus afgelei sal word.

\section{Groei en verval van kerke en predikantsopleiding}

Baie van die nuwe besinning oor teologiese opleiding word gestimuleer deur dit wat in Christelike kerke aan die gebeur is - of in sommige plekke juis nie gebeur nie. Aan die een kant is daar verstommende getallegroei van Christelike kerke in die Ontwikkelende Wêreld en ' $n$ baie groot nood aan opgeleide predikante. Aan die ander kant is daar sterk afnemende getalle in "blanke" Westerse kerke en dikwels 'n algehele gebrek aan missionêre visie en ywer om te evangeliseer.

\subsection{Gebrek aan groei en missionale roeping na vernuwing in opleiding}

Die kerk van Christus is per definisie 'n missionêre gemeente. Te veel voorgangers voltooi hulle teologiese opleiding met 'n eensydige na binne gerigte visie op kerkwees (Miller, 1986:17). Teologiese skole, kurrikula en modelle van predikantsopleiding word dikwels ge- 
sien as struikelblokke vir kerkgroei. Ralph Winter (2003:11) formuleer hierdie klag soos volg:

... it is sad yet fair to say that the seminaries and Bible schools of the world are actually a surprisingly weak and often negative contributor to the growth of Christianity around the world.

Die na binne gerigtheid van voorgangers en gemeentes lei daartoe dat kerke kwyn en wegsterf. Miller (1986:17) skryf vanuit 'n Calvinistiese paradigma oor wat in kerke gebeur en verwoord hierdie proses so:

Ingrown Churches and their leaders have crashed spiritually and never noticed their own fatal ending. The evidence is easily found in their lack of zeal for outreach. In some cases, congregations and their leaders have even come to suspect zeal for witness as evidence of fanaticism - or at least a sign of immaturity. Other congregations still give lip service to missions and evangelism, but inwardly they have given up - quit having lost confidence in their being used by the Lord of the harvest to bring people to Him.

Oor 'n periode van 30 jaar het ek dikwels GKSA se teologiese studente ontvang wat by my praktiese evangelisasie-opleiding kom doen het en die volgende opmerkings gemaak het:

Ek het nog nooit gedurende my opleiding geleer hoe om met 'n buitekerklike op 'n eenvoudige manier oor geloof in Christus te praat nie. Noudat ek die eerste keer regtig gesien het hoe ongelowiges tot bekering kom, sal my eie lewe nooit weer dieselfde wees nie.

Die Gereformeerde Kerke in Australië (CRC, 2006) het in 2006 as resultaat van indringende missionêre strategiese beplanning besluit om biddend, doelgerigte groeiprosesse aan die gang te sit. Hulle het besluit om gemeentes toe te rus, op te lei en te stimuleer om soveel as moontlik nuwe gemeenskappe (bedieningspunte) en gemeentes te laat ontstaan om gelowiges sodoende toe te rus om samelewingstrukture met die evangelie te deursuur en hulle naaste vir Christus te wen. Hulle wou die hoeveelheid goed toegeruste persone (georden of ongeorden, voltyds, deeltyds of vrywilligers) vermenigvuldig wat liefdevol daaraan toegewy is om sulke bedieningspunte en nuwe gemeentes deur die verkondiging van die evangelie te ontwikkel. Hulle het daarom ook besluit om die aantal jare van voltydse residensiële studie van toekomstige predikante by die amptelike teologiese skool in Geelong te verminder en 'n aantal jare van kerkgebaseerde (church based) in-diens-teologiese opleiding in 
te stel deur gebruik te maak van die opleidingsmateriaal van BILD international. 1

\subsection{Gebrek aan missionêre krag in kerke in die ontwikkelde wêreld}

Sendingwetenskaplikes en teoloë wat oor die missionêre krag van kerke in die Weste besin, beweer dat een rede vir 'n gebrek aan missionêre ywer en effektiwiteit van kerke, die gevolg is van verkeerde modelle van predikantsopleiding. Dit is daarin geleë dat toekomstige predikante nie geleer word hoe om werklik die evangelie so te bedien en gemeentes so te lei om werklik misionêre kerke te wees nie. Wanneer kerke nie groei nie moet teologiese opleidingsinstansies hulleself ook ernstig hieroor ondersoek en vra waarom hulle nie predikante lewer wat missionêre ywer het en daarin slaag om gemeentes se missionêre visie, ywer en effektiwiteit te verbeter nie. In hierdie verband wys Peter Wagner, wat veertig jaar van sy lewe by teologiese opleiding betrokke was, sewe grafstene uit onder die opskrif: Why seminaries are sometimes called "cemeteries" (vgl. Dreyer, 2003:106).

- Grafsteen 1: Akademiese prestasie word belangriker as bedieningsvaardighede geag.

- Grafsteen 2: Die hoogste prioriteit is dikwels om akademiese eweknieë te beindruk, nie om studente op te lei nie.

- Grafsteen 3: Akademiese uitnemendheid vind neerslag in die klimaat van die teologiese opleidingsinstansie en in die verwagte kursusse.

- Grafsteen 4: Dosente aan teologiese opleidingsinstansies het nie altyd veel bedieningservaring nie.

- Grafsteen 5: Teologiese opleidingsinstansies is verantwoording verskuldig aan hulle geakkrediteerde instansies en nie soseer

1 BILD is die akroniem vir Biblical Institute for Leadership Development. Die uitgangspunt van hierdie instituut is dat die konteks van teologiese opleiding die vermenigvuldiging en tot standkoming van plaaslike kerke moet wees. Op hierdie manier word karaktervorming, ontwikkeling van vaardighede en akademiese vorming van teologiese studente geïntegreer in 'n tipe "vakleerlingskap"-opleiding onder die begeleiding van 'n gekwalifiseerde en ervare predikant in die konteks van die samelewing. Behalwe dat dit ' $n$ beter model van teologiese opleiding as voltydse residensiële opleiding is, is dit in die lig van groot afstande, vir studente en die kerkverband ook 'n goedkoper model van opleiding. 
aan die kerk waarvan hulle veronderstel is om die predikante op te lei nie.

- Grafsteen 6: Die aard van akademiese instellings is om kritiese denke in die hele samelewing te stimuleer.

- Grafsteen 7: Teologiese opleiding prys homself uit die mark.

In Duitsland het die Evangelische Kirche hierdie probleem van predikante wat nie toegerus is om gemeentes te lei om missionêre gemeentes te wees nie, so sterk onder die aandag gebring dat daar sedert 1992 'n "Pastoralkoleg Urach" in Bad Urach naby Tübingen onder leiding van Karl Renstich vir die "heropleiding van predikante" ontstaan het. Daar het 'n sterk oortuiging ontstaan dat gemeentes nie missionêr ingestel is nie en nie uitreik na byna $90 \%$ van die Duitse bevolking wat buite-kerklik is nie omdat voorgangers ook nie toegerus is om die gemeentes te lei om missionêre gemeentes te wees nie. Karl Renstig was jare lank sendeling in Indië en met sy terugkeer na Duitsland het hy ontdek dat Wes-Duitsland net so ongekerstend en buitekerklik geraak het as Indië. Hy is versoek om met 'n heropleiding van predikante te begin om hulle toe te rus hoe om gemeentes weer missionêre gemeentes te laat word. Oor die oogmerke van hierdie opleiding is Renstich (1993:3) eksplisiet:

Ziel der Arbeit des Pastoralkoleg's Urach soll es sein, realistische Modelle für Gemeindeaufbau/Gemeindeerneuerung zu arbeiten und zukunftsorientierte Gemeindeformen zu finden, die es Theologen und Laien gemeinsam ermöglichen, bewuszt als Christen in der säkularen, multikulturellen und multireligösen Gesellschaft zu leben.

In Australië het die Presbyterian Church ook besef dat die kerke nie groei nie en die aantal mense wat hulleself aanmeld vir predikantsopleiding drasties verminder het. Dit het daartoe gelei dat onder leiding van ds. David Jones 'n kerkplantaksie begin is. Persone wat daarby betrokke raak, kry 'n basiese indiensopleiding in evangelisasie, dissipelskap en kerkplanting ('n soort evangeliste-opleiding). Nadat hulle hul roeping en gawes vir 'n aantal jare in sulke evangelisasie- en kerkplantaksies bewys het, gaan hulle vir 'n verdere aantal jare na die amptelike teologiese skool van die kerk om formele predikantsopleiding te ontvang. Dit het daartoe gelei dat meer mense weer as predikante opgelei word en dat nuwe gemeentes ook ontstaan het. 


\subsection{Eksplosiewe groei in die ontwikkelende wêreld, veral Afrika, Asië en Suid-Amerika roep na meer en nuwe modelle van predikantsopleiding}

Verskeie navorsers wys daarop dat die sentrum van die Christendom reeds van die Noordelike halfrond na die Suide verskuif het (vgl. Jenkins, 2002). In die Februarie 2000-uitgawe van die tydskrif Time Europe het 'n artikel verskyn wat aantoon dat die Christendom in Afrika suid van die Sahara op die oomblik vinniger as op enige ander plek in die wêreld in getalle groei.

Dit word bereken dat daar wêreldwyd tans 4000 nuwe gemeentes per week tot stand kom en dat dit in die volgende drie jaar sal groei na 12000 per week. Daar is meer as drie miljoen kerklike voorgangers wat 'n gebrek aan basiese Bybelse opleiding en bedieningsvaardighede het (Landrey, 2009).

Vir die Afrikakontinent is die skatting dat daar weekliks 300 nuwe gemeentes tot stand kom (Buys, 1999). Die Evangelies Christelike Kerk in Zambië het byvoorbeeld 675 gemeentes, maar slegs 30 opgeleide predikante. ' $n$ Ander kerk in Oeganda het 1000 gemeentes, maar slegs agt opgeleide predikante.

Die mees invloedryke kerk in Zambië is die United Church of Zambia. Hierdie kerk het ontstaan toe die Gereformeerd Presbiteriaanse Kerk en die Church of Scotland besluit het om saam te smelt. Hulle het tans meer as 'n miljoen lidmate. Daar is egter gevalle waar een opgeleide predikant 50 gemeentes bedien.

Die Overseas Council for Theological Education het op grond van navorsing en rapporte oor 'n wye front tot die gevolgtrekking gekom dat tussen $80 \%$ en $90 \%$ van die byna drie miljoen voorgangers van Christelike kerke in die Derde Wêreld nooit deur formele residensiële opleiding bereik sal word nie. Daarom sal hulle deur ' $n$ verskeidenheid nie-formele afstandsonderrigprogramme bereik moet word. Indien dit nie gebeur nie, is die gevaar van sinkretisme groot soos wat dit reeds op baie plekke waargeneem kan word.

Reeds in 1979 en weer in 1988 het Kritzinger (1979:33; 1988:2) gewaarsku dat die kerke in Afrika hulleself doodgroei! Die strukture en gebrek aan bekwame voorgangers en meer volwasse Christene, kan die massale invloei van nuwe Christene nie hanteer nie.

Verskeie sendingwetenskaplikes (Conn, 1979:317 e.v.; Hopewell, 1969:20; Winter, 2003:11), wat besorg is oor die nood aan teologiese opleiding in die kerke in die armer dele van die wêreld, som 
die probleme van tradisionele teologiese opleiding deur tradisionele opleidingsinstansies en universiteite soos volg op:

- Daar word nie genoeg voorgangers opgelei nie.

- Die ware voorgangers word nie opgelei nie.

- Die tradisionele manier van opleiding is onbetaalbaar duur.

- Potensiële voorgangers word deur die tradisionele opleiding te lank uit hulle natuurlike woon- en werksomgewing (en dikwels kultuur) afgesonder. Hulle word professionele, akademies goedgeskoolde mense wat dikwels na afloop van hulle opleiding nie meer met hulle eie mense onder wie hulle moet gaan werk, identifiseer nie en ook nie meer deur hulle aanvaar word nie.

- Die inhoud van tradisionele (Westerse akademiese) predikantsopleiding is dikwels irrelevant vir die werklike pastorale nood van die kerke en die wêreld waar die voorganger moet gaan werk.

Die vraag kan gevra word of ons in Suid-Afrika besig is met die regte model van kultureel-relevante opleiding as lidmaatgetalle en gemeentes wel toeneem, maar daar in so baie gemeentes nog so baie probleme voorkom. Hierdie probleme word dikwels nie in die kurrikula van predikantsopleiding aangeraak nie en sluit die volgende in:

- verering van voorouergeeste;

- pynlike stryd en twis aan die gang oor vroue se kerklike kleed;

- begrafnispraktyke en rougebruike wat voorkom en geen Bybelse begronding het nie en deurspek is met Afrika se tradisionele godsdiensgebruike;

- weinig gemeentes kan werklik finansieel selfstandig die mas opkom;

- baie predikante doen alles in hulle vermoë om kapelaanswerk in regeringsdienste te kry om finansieel te kan oorleef;

- sommige predikante verlaat hulle gemeentes en vir beter finansiële voordele emigreer hulle na die buiteland.

Navorsers op die gebied van ontwikkelingshulp en die oorsake van armoede is van mening dat een van die vernaamste oorsake van die groeiende armoede in Afrika die oorblyfsels van 'n animistiese wêreldbeeld is. As gevolg van oppervlakkige kerstening oorheers hierdie wêreldbeeld nog mense se denke oor arbeidsetiek en die gebrek aan roepingsbewuste kreatiwiteit (Miller, 2001:55; Van der Walt, 
1999:89-148; Muriithi 1996:55; Van Niekerk, 1994:24, Van Rooy, 1994:266).

Dit is ook die oortuiging van die Afrika-streek van die ICRC (International Conference of Reformed Churches) se vergadering in Lubumbashi in November 2003:

The Reformed Churches in Africa are convinced that religious pluralism is not the appropriate cure to the poverty in Africa, since this pluralism does not put into question non-biblical worldviews, which are characterized by sin.

\section{3. 'n Nuwe besinning oor Bybelse beginsels}

Dit is verblydend om te sien dat daar die laaste dekades deur teoloë, sendingwetenskaplikes en studierapporte van allerlei instansies opnuut en indringend gevra word na Bybelse beginsels oor die opleiding van voorgangers in die gemeente. Daar is 'n ernstige poging aan die gang om bo-oor historiese tradisies na die Skrif terug te gaan (Decarvalho, 2003; Cole, 2001:41-77; Allen, 1983; Barclay, 1980; Covell \& Wagner, 1971).

\subsection{Paulus en Timoteus se toerusting}

Opleiding in die Nuwe-Testamentiese kerk was baie nóú verbonde aan die gemeente en primêr gerig op diens aan die Here in die opbou van sy gemeente.

In hierdie verband is dit goed om Paulus se opleiding van Timoteus onder die loep te neem en prinsipiële en praktiese riglyne daaruit af te lei oor die kurrikulum, leerinhoude, wyse van onderrig (didaktiek), keuring van studente en onderrigkonteks. Die werk van Cole (2001) plaas belangrike perspektiewe op die agenda vir ernstige oorweging.

Cole (2001:130) is van mening dat duidelik aangetoon kan word dat Christelike karaktervorming van studente (Timoteus) vir Paulus (as toeruster) die heel belangrikste onderrigdoel was. Die leer (Cole noem dit body of doctrines) wat oorgedra is, was daarop ingestel om die geestelike karakter van Timoteus te vorm en te transformeer. Hy moes al meer aan die beeld van Christus gelyk word en nie bloot kognitiewe feite in 'n eksamen weergee nie. Indien Paulus gevra kon word of die rasionaal van die leerinhoud wat hy oorgedra het slegs maar was dat Timoteus ' $n$ groot aantal feite sou ken wat hy weer aan ander kan oordra, sou Paulus se antwoord beslis ontkennend wees. Op die vraag of die bedoeling was dat Timoteus deur die kerk 
van Listra beroepbaar gestel kon word sou hy ook ontkennend antwoord. Op die vraag wat die rasionaal van sy leerinhoude dan was, sou hy sê: "Sodat Timoteus 'n man van God kan wees ... volkome voorberei en toegerus ... vir elke goeie werk" (2 Tim. 3:17).

Cole sluit hom by verskeie navorsers aan wat aantoon dat die opleiding van voorgangers hoofsaaklik drie doelwitte het.

- Primêr is die doel om studente se karakters en diepste geestelike oortuigings te vorm, want dit sal hulle betroubaarheid in hulle dienswerk bepaal. Hy formuleer: "Beliefs are what we hold, but convictions are what holds us."

- Tweedens moes hulle bepaalde kennisinhoude hulle eie maak. Die keuse van leerinhoude is deur Skrifwaarhede bepaal wat juis op die geestelike karaktervorming van studente gerig was.

- Derdens moes hulle algaande toepaslike praktiese bedieningsvaardighede hulle eie maak.

\subsection{Die voorganger as man van God}

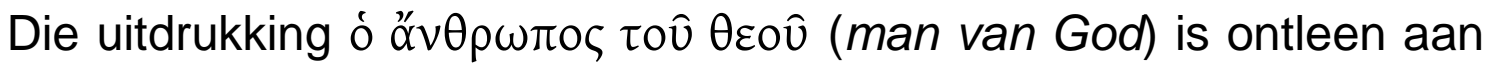
die Ou Testament en dui op 'n persoon wat 'n voorbeeld van toewyding aan God is en juis om hierdie rede kwalifiseer om 'n voorganger in die kerk te wees (1 Tim. 6:11; 2 Tim. 3:17). óv $\theta \rho \omega \pi \circ$

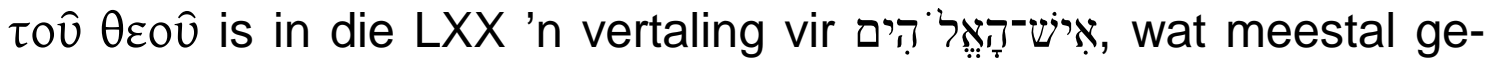
bruik is om profete aan te dui (1 Kon. 12:22; 13:1; 17:18, 24), ook ten opsigte van Moses (Deut. 33:1), maar ook ten opsigte van Dawid (2 Kron. 8:14).

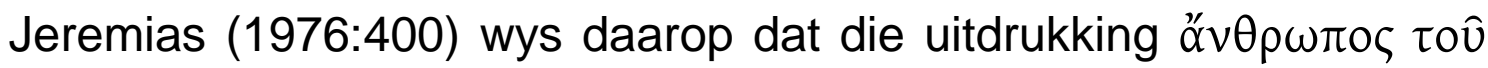
$\theta \varepsilon$ ov nie 'n onafhanklike konstruksie is nie, maar uit die gebruik daarvan in die Septuaginta ontwikkel het. Daarom lê die oorsprong van hierdie uitdrukking in die Nuwe Testament nie in die mistieke godsdienste nie, maar in die gebruik van die begrip in die $\mathrm{Ou}$ Testament. Die man van God is iemand wat in diens van God staan, as verteenwoordiger van God optree en in die Naam van God praat, soos Moses (Deut. 33:1), Samuel (1 Sam. 9:6), Elia (1 Kon. 17:18), Elisa (2 Kon. 4:7) en Dawid (Neh. 12:24).

\subsection{Kernwaardes van die man van God}

Binne die konteks van 1 Timoteus 6:1-21 en 2 Timoteus 3:15-17 is dit duidelik dat die man van God gekarakteriseer word deur bepaalde kernwaardes. 
$\mathrm{Hy}$ is bo alles iemand wie se lewe deur godsvrug gekenmerk word

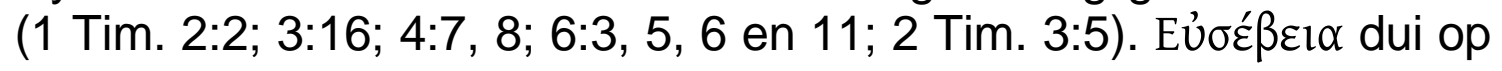
'n gesindheid van liefde en ontsag, toewyding en oorgawe aan God self, wat op sy totale lewe beslag lê en 'n impak het op alle ander menslike verhoudings. Dit dui op die kinderlike vrees vir die Here.

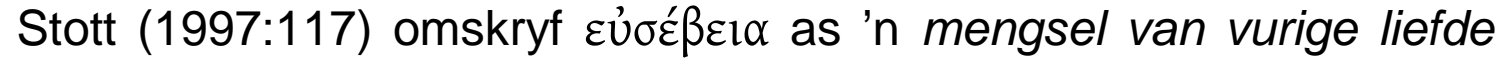
en heilige ontsag.

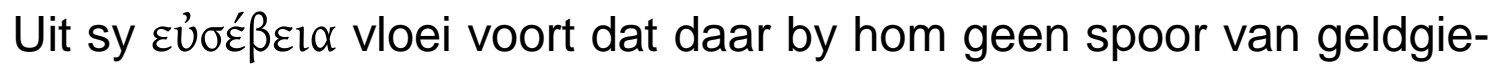
righeid mag wees nie en sy houding gekenmerk word deur tevredenheid met die vervulling van basiese lewensbehoeftes.

'n Lewe van godsvrug ( $\varepsilon \dot{\sigma} \sigma \varepsilon ́ \beta \varepsilon l \alpha)$ is egter meer as 'n eenvoudige "bourgeois" lewenstyl. In 2 Timoteus 3:12 word 'n godvrugtige lewe

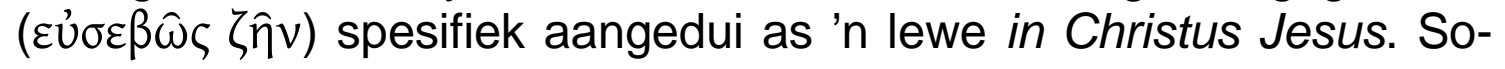
doende het 'n lewe van ware godsvrug 'n duidelike Christologiese

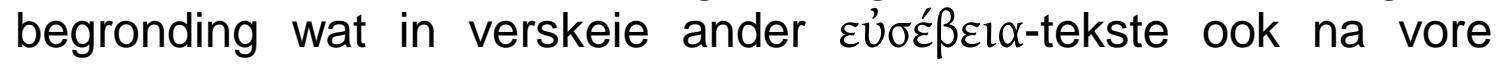
gebring word (vgl. Tit. 1:1). Dit staan juis in teenstelling met die valse leraars waarvan in 1 Timoteus 6:3 gesê word dat hulle met Jesus Christus self bots. Hulle is naamlik verwaand, het 'n sieklike sug na twisvrae en woordestryd. Hulle is vol afguns, twis, lastering,

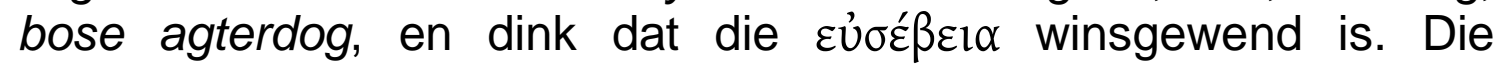

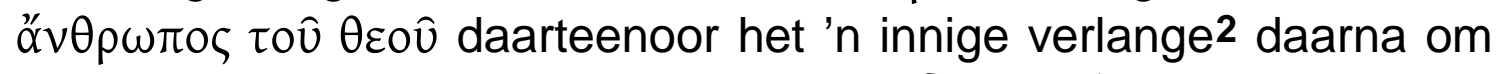

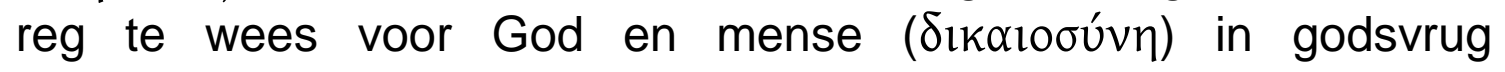

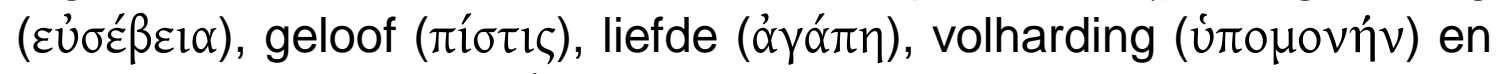
minsaamheid ( $\pi \rho \alpha \ddot{u} \pi \alpha \theta i ́ \alpha v)$.

Dit is belangrik om raak te sien dat Paulus aan Timoteus die opdrag gee om versigtig, akuraat, verantwoordelik en vrymoedig die evangelie van God se genade in prediking en onderrig te verkondig. Hy moet nie bang wees om die dwaalleer van demoniese leerstellings bloot te lê en op 'n deursigtige manier dit wat hy aan ander leer self uit te leef nie. Timoteus moet in leer en lewe en in die groei in vroomheid en godsvrug 'n voorbeeld vir ander wees. Die geheim van die godsvrug, naamlik God se totale heilsplan (1 Tim. 3:16), moet sentraal staan as die hart van sy onderrig en verkondiging. Hy moet ander voorgangers onderrig wat weer op hulle beurt ander sal onderrig (2 Tim. 2:2).

2 Die NAV-vertaling van streef na laat nie werklik reg geskied aan die intensiteit van $\delta ı \omega ́ k \omega$ nie. Louw et al. (1989:69) vertaal: "to do something with intense effort and with definite purpose or goal - 'to do with effort"'. 
Hierdie waardes is nie net in 'n klaskamer of lesingsituasie oorgedra nie, maar in die praktiese, alledaagse gesamentlike bedieningswerk deur die dosent (Paulus) aan die student (Timoteus) gemodelleer. Timoteus het Paulus se voorbeeld van leer, lewenswandel en lewensdoel, in geloof, geduld, liefde en volharding, selfs te midde van vervolging en ontbering (2 Tim. 3:10) waargeneem en nagevolg. Die student het 'n vakleerlingskap deurloop waarin hy aanvanklik slegs waarneem en dan algaande groter verantwoordelikhede oorneem na die mate wat hy sy betroubaarheid bewys.

Zemek (1993) het 'n indringende studie oor die kardinale waarde van modellering in die totale bediening van die evangelie gedoen. Uit die Nuwe Testament toon hy oortuigend aan dat voorbeeld en modellering 'n wesenlike aspek van aktiewe onderrig in die opleiding sowel as in die bediening van predikante in die gemeente en selfs van een gemeente aan ander gemeentes is. Daarom kan Paulus ook vir die gemeente in Filippi skryf: "En wat julle van my geleer en ontvang het, en gehoor en gesien het, dit moet julle doen. En God wat vrede gee, sal by julle wees" (Fil. 4:9).

In hierdie verband het Harvie Conn opgemerk: "The Biblical model of 'edification', is a God-centered call to build up others (Rom. 15:2), not through the service of cognitive abstraction alone, but through love (1 Cor. 8:1)."Cole (2001:145) en Farley (1983:11) maak die opmerking dat die meeste teologiese opleidingsinstansies 'n geweldige leemte openbaar deur die vordering van studente hoofsaaklik te meet aan hulle vermoë om feitekennis in 'n eksamen weer te gee en miskien nog hulle praktiese vaardighede te evalueer. Die heel belangrikste, naamlik hulle groei in godsvrug, word egter byna nie gemeet nie, omdat dit eintlik slegs in 'n intieme mentorskapsverhouding werklik geëvalueer kan word.

'n Belangrike punt vir Cole en ander skrywers oor toerusting vir die bediening, is dat studente se roeping en gawes reeds deur dienswerk in kerke moes sigbaar word voordat hulle met predikantsopleiding begin. Paulus se kriteria vir voorgangers is juis dat hy nie 'n nuwe gelowige moet wees nie, maar reeds homself sodanig bewys het dat hy as 'n goeie man bekend staan. Daar moet nie veragtelike praatjies oor hom ontstaan en hy in die greep van die duiwel kom nie (1 Tim. 3:7).

Winter (2003:11) stel dit nogal sterk as hy sê:

The most severe problem is the simple fact that $90 \%$ of the students in pastoral training are not the seasoned mature 
believers defined by the New Testament as candidates for pastoral leadership. Both in the U.S. seminaries and in some four or five thousand overseas Bible Institutes, Theological Colleges etc. the vast majority of the students will never be effective pastors, no matter what or how or where they were taught, simply because they may lack pastoral gifts and at their age and level of maturity there is no way to predict that they will ever gain the essential gifts and maturity.

'n Belangrike punt wat taamlik algemene konsensus ontvang het, is dat op grond van Efesiërs 4:7-16 daarop gewys word dat teologiese opleiding té rigied slegs predikante oplei. Daar moet veel meer diversiteit, intree- en uittreevlakke en 'n veel breër spektrum toerusting van gelowiges in opleidings aangebied word. Opleiding moet ook poog om kerke met allerlei formele en nie-formele toerusting vir gelowiges te dien om hulle roeping in die amp van die gelowige te kan vervul.

Die ICTE-manifes noem in hierdie verband "strategic flexibility" in teologiese opleiding en spreek dan die volgende versugting uit:

Too long we have been content to serve the formation of only one type of leader for the church, at only one level of need, by only one educational approach. If we are to serve fully the leadership needs of the body of Christ, then our programmes singly and in combination must begin to demonstrate much greater flexibility in at least three respects. Firstly, we must attune ourselves to the full range of leadership roles required, and not attend only to the most familiar or most basic. To provide for pastoral formation, for example, is not enough. We must also respond creatively, in cooperation with other programmes, to the church's leadership needs in areas such as Christian education, youth work, evangelism, journalism and communications, TEE, counselling, denominational and parachurch administration, seminary and Bible school staffing, community development, and social outreach.

\section{Enkele modelle in die praktyk}

\subsection{Paradigmaverskuiwing in predikantsopleiding by die Hindustan Bible Institute and College}

Een interessante voorbeeld is die verandering in opleiding wat die Hindustan Bible Institute and College in sy kurrikulum en styl van opleiding aangebring het (Raja, 2005:1-7). Hierdie inrigting het in 1952 tot stand gekom en bied verskillende sertifikate, diplomas, B.Th.-, M.A.-, M.Div.- en M.Th.-grade aan. Tot 1980 was dit 'n ge- 
wone akademiese opleidingsinstansie wat gestruktureer was om kennis en begrip en laastens vaardighede by studente tuis te bring.

Daar is egter besef dat alhoewel hierdie styl van opleiding goeie predikante vir gevestigde gemeentes opgelewer het, daar min sendelinge en evangeliste uit hierdie soort opleiding na vore gekom het. Baie studente het volgens dr. Bobby Gupta (Raja, 2005:2), die rektor, verder studeer en meer akademiese kwalifikasies behaal met die hoop om sodoende nie vir sending- en evangelisasieberoepe te kwalifiseer nie. Kerke het hierdeur begin stagneer.

Sedert 1987 is die hele opleidingstyl verander. Die verandering het met ' $n$ verandering van fokus begin. Predikantsopleiding is daarop gefokus dat elke kerk 'n missionêre kerk moet word. Deur die bediening van predikante en die gemeentes waar hulle werk moet elke Indiër in die hele land die geleentheid kry om die evangelie te hoor, te verstaan en daarop te reageer. Mense wat tot bekering kom, moet begelei word om in die gemeenskap van 'n gemeente geestelik-volwasse gelowiges te word wat self reproduserende dissipels van Jesus Christus word, deurdat hulle Christus in alles wat hulle is en doen uitstraal.

Dr. Armaity S. Desai (Raja, 2005:6) het in die tyd verklaar:

As ons gemotiveerde studente en dosente wil hê wat werklik die passie ontwikkel dat elke gemeente in die Naam van die Here 'n missionêre gemeente moet word, sal ons drastiese veranderinge in ons hele struktuur van opleiding moet aanbring sodat Bybelse beginsels en praktiese uitlewing daarvan werklik beleef sal word dwarsdeur die hele periode van opleiding.

Die paradigmaverskuiwing het ingehou dat die opleiding eers op sending en evangelisasiewerk fokus, daarna op kerkplanting (totstandkoming van nuwe gemeentes) en laastens op predikantskap in 'n bestaande gemeente. Die volgorde in die leerproses van studente is verander na ervaring/toepassing, daarna beginsels, daarna bestudering van teorieë.

Gedurende die eerste twee jaar word studente hoofsaaklik as evangeliesasiewerkers opgelei. Daarna vir twee jaar as kerkplanters en dan vir die laaste drie jaar as predikante. Gedurende die hele opleiding vind slegs $20 \%$ van die leerproses in 'n klaskamer plaas en die ander $80 \%$ in praktiese veldwerk. Hulle gaan doen in groepe veldwerk en kom slegs enkele dae per maand of enkele ure per week vir formele klasse byeen. 
Die bedoeling van die opleiding is om pedagogie (dosent afhanklike leer), andragogie (selfstandige leer) en synergogie (interafhanklike leer) te sinkroniseer. In alles moet Christus self nagevolg en weer uitgestraal word. Die impak van hierdie transformasie in die opleiding was na 'n aantal jare die volgende: 2094 nuwe kerke of aanbiddingsplekke onder 45 verskillende bevolkingsgroepe het in sestien provinsies van Indië tot stand gekom; 101255 ongelowiges en buitekerklikes het lidmate van die kerk geword; Raja (2005:7) beweer dat in Indië deesdae tussen 8000 en 10000 mense per dag Christene word.

\subsection{Nieu-Mexico-opleiding van CRC-predikante}

In Nieu-Mexico (Arizona) in die VSA het die Christian Reformed Church vir 80 jaar probeer om Indiaanse (Navajo- and Zunisprekende) predikante uit Klassis Red Mesa uit hulle gebied weg te stuur vir jarelange opleiding by Calvin College in Grand Rapids. Algaande het hulle egter besef dat dit nie werk nie. Die predikante het tydens hulle opleiding 'n totaal ander lewenstyl aangeleer. Met hulle terugkeer na Nieu-Mexico het hulle ervaar dat hulle soos Dawid met Saul se uitrusting probeer om met Goliat te veg en dikwels die stryd verloor. Heel weinig van die opgeleide predikante van Grand Rapids kon die mas opkom in die praktiese bediening in Nieu-Mexico en hierdie kerke het gesukkel en gekwyn.

Sedert die laat tagtigerjare is die hele opleiding van predikante egter na indiensopleiding verander. Kerke in die Klassis het saam 'n predikant beroep wat die opleiding koördineer. Studente moet op grond van hulle gawes en roeping deur die kerke geïdentifiseer word en onmiddelik in die gemeente met bedieningswerk begin. Hulle kom maandeliks vir 'n week op 'n sentrale punt bymekaar waar hulle onderrig en werksopdragte ontvang. Dit word aan hulle kerkrade gerapporteer en die kerkraad sorg dat studente se opdragte in die gemeente verband hou met die leerinhoude wat hulle besig is om te bemeester. Die hele opleiding word sterk deur mentorskap van die plaaslike predikant vir die student in opleiding gestempel. Die resultaat is dat daar tans in 20 jaar meer en beter kwaliteit predikante gelewer word as die vorige 80 jaar. Die gemeentes het ook weer in getalle sowel as in geestelike kwaliteit gegroei.

\section{Enkele gevolgtrekkings}

Uit die Bybelse beginsels en hedendaagse internasionale tendense en publikasies is dit duidelik dat die groot aandrang na 'n sterker fokus op leer deur ervaring in die praktyk en 'n duidelike klem op 
godsvrug en karaktervorming in predikantsopleiding nie net Skrifgetrou is nie (Cole, 2007:173), maar ook tot meer geestelike volwassenheid en doelgerigtheid by studente lei, asook tot kerkgroei en die totstandkoming van werklike missionale gemeentes (Frame, 1984:369-388).

Karaktervorming en die geestelike groei van studente moet deeglik bepaal en gemeet word ten einde op 'n holistiese manier voorgangers te lewer wat werklik Manne van God in hulle bediening sal wees.

Indien al die vakgebiede in die teologiese opleiding werklik daarop gerig is om God in al sy majesteit en soewereine genade en die implikasies daarvan vir elke aspek van kerkwees te verheerlik, sal elke teologiese vakgebied deursuur wees met 'n missionêre gerigtheid (Ortiz, 1997:1-12).

Meer effektiewe leer sal juis plaasvind as die leerproses in die klaskamer en die leerproses in die praktyk maksimaal gesinkroniseer word.

Die voorbeeld van vele gereformeerde kerke wêreldwyd wat die waarde van indiensopleiding ontdek het, verdien die ernstige oorweging van die Gereformeerde Kerke in Suid-Afrika. Daar moet indringend na naatlose verbindingsmoontlikhede tussen informele, nie-formele en formele residensiële teologiese opleiding gesoek word deur veel meer modelle van afstandsonderrig te ontgin.

\section{Geraadpleegde bronne}

ALLEN, R. 1983. Missionary methods: St. Paul's or ours. Grand Rapids: Eerdmans.

BARCLAY, W. 1980. Educational ideals in the ancient world. Grand Rapids: Baker Book House.

BOSCH, D.J. 1984. Missions in theological education. (In Conn, H.M. \& Rowen, S.F., eds. Missions \& theological education in world perspective. Farmington: Associates of Urbanus. p. xv-xli.)

BUYS, P.J. 1999. Manila topic '99 report: back to the drawing board with theological education to reach at least two million untrained pastors in economically weaker areas of the world. www.topic.us/ Date of access: 15 Aug. 2009.

CHRISTIAN REFORMED CHURCHES OF AUSTRALIA. 2006. Ministry formation Christian reformed churches of Australia: a church reforming to reach the lost for Christ. http://www.ministryformation.crca.org.au/ index.php? option=com_content\&view=article\&id=55\&Itemid=41 Date of access: 14 Aug. 2009.

COLE, V.B. 2001. Training of the ministry: a macro-curricular aproach. Bangladore: National Printing Press. 
COLE, V.B. 2007. Sharing the oportunity for ministerial spiritual formation. (In Logan, S.T., ed. Confronting kingdom challenges: a call to global Christians to carry the burden together. Wheaton: Crossway Books. p. 169-196.)

CONN, H.M. 1979. Theological education and the search for excellence. Westminster theological journal, 41:311-363.

COVELL, R.R. \& WAGNER, C.P. 1971. An extension seminary primer. Pasadena: William Carey Library.

$\mathrm{CRC}$

see CHRISTIAN REFORMED CHURCHES OF AUSTRALIA

DE VILLIERS, D.R. 1976. Training the ordained minister. (In Reformed Ecumenical Synod. Training for missions. Grand Rapids: RES. p. 51-73.)

DECARVALHO, L. 2003. Jesus' model of education. Mission frontiers, 23(2):1.

DREYER, D. 2003. Nie ter wille van onsself nie: lééf jou gemeente regtig? Wellington: Lux Verbi.BM.

ELISTON, E.J., ed. 1999. Teaching them obedience in all things: equipping for the 21st century. Pasadena: William Carey Library. (Evangelical Missiological Society, series 7.)

FARLEY, E. 1983. Theologia: the fragmentation and unity of theological education. Philadelphia: Fortress.

FERRIS, R. 2001. The role of theology in theological education. (In Elmer, D. \& McKinney, L., eds. With an eye on the future: development and mission in the 21st century. Monrovia: MARC. p. 101-111.)

FRAME, J.M. 1984. Proposals for a new North-American model. (In Conn, H.M. \& Rowen, S.F., eds. 1984. Missions \& theological education in world perspective. Farmington: Associates of Urbanus. p. 369-388.)

HAAK, C.J. 1999. Demonstratie van Gods genade: theologische opleiding in missionair perspectief. (Ongepubliseerd.) (Inleiding in de gereformeerde missiologie en oecumenica, dl. 8.)

HART, D.G. \& ALBERT MOHLER, R. Jr., eds. 1996. Theological education in the evangelical tradition. Grand Rapids: Baker Books.

HOPEWELL, J.F. 1969. Ministry and training: a crisis in identity. (In Winter, R.D. Theological education by extenstion. South Pasadena: William Carey Library. p. 70-80.)

HOUGH, J.C. \& COBB, J.B. 1985. Christian identity and theological education. Chico: Scholars Press.

JENKINS, P. 2002. The next Christendom: the rise of global Christianity. Oxford: Oxford University Press.

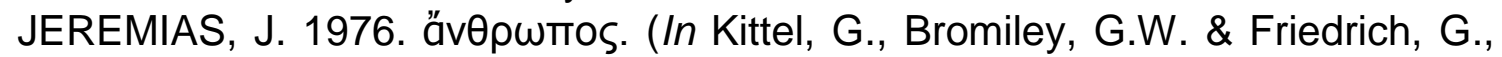
eds. Theological Dictionary of the New Testament. Grand Rapids: Eerdmans. p. 364-365.)

JIM, S.W. 2003. From missioned to mission: an interview with Stanley W. Jim. Gathering magazine, Summer.

KORNFIELD, D. 1984. Seminary education toward adult education alternatives. (In Conn, H.M. \& Rowen, S.F., eds. Missions \& theological education in world perspective. Farmington: Associates of Urbanus. p. 169-221.)

KRITZINGER, J.J. 1979. 'n Missionêre bediening: op weg na strukture vir 'n jong kerk. Pretoria: NG Kerkboekhandel. 
KRITZINGER, J.J. 1988. Biblical guidelines for the training of leaders for the nurture of the church in Africa. Paper delivered at a Conference regarding Training of Church Leaders in Africa, Potchefstroom, 9-12 August 1988. (Unpublished.)

LANDREY, J.P. 2009. Trainers of pastors international coalition. www.topic.us/ Date of access: 15 Aug. 2009.

LOUW, J.P., NIDA, E.A., SMITH, R. \& MUNSON, K.A. 1989. Greek-English Lexicon of the New Testament based on Semantic Domains. 2nd ed. New York: United Bible Societies.

MILLER, C.J. 1986. Outgrowing the ingrown church. Grand Rapids: Zondervan.

MILLER, D.L. 2001. Discipling nations: the power of truth to transform cultures. Seatle: YWAM Publishing.

MURIITHI, S.M. 1996. African crisis: is there hope. New York: University Press of America.

NEWBIGIN, L. 1984. Theological education in world perspective. (In Conn, H.M. \& Rowen, S.F., eds. Missions \& theological education in world perspective. Farmington: Associates of Urbanus. p. 3-18.)

NIEBUHR, R.H., WILLIAMS, R. \& GUSTAFSON, J.M. 1957. The advancement of theological education. New York: Harper.

ORTIZ, M. 1997. Seminary: a place for missiological preparedness. Westminster theological journal, 59:1-12.

PIPER, J. 1999. Training the next generations of evangelical pastors. (In Elliston, J., ed. Teaching them obedience in all things: equipping for the 21st century. Pasedena: William Carey Library. p.16-31.)

RAJA, I.S. 2005. Review of pastoral leadership training: case study of Hindustan Bible Institute model. Paper delivered at TOPIC Indian in Kolkata in 2005. (Unpublished.)

RENNSTICH, K.W. 1993. Pfarrerfortbildung in einer pluralistischen Gesellschaft am Beispiel des Pastoralkollegs Urach. Vortrag Pfarrkonvent Stuttgart am 9. Juni 1993. Bad Urach: Pastoralkolleg.

SCHROTENBOER, P.G.1976. Training for missions. (In Reformed Ecumenical Synod. Training for missions. Grand Rapids: RES. p. 3-25.)

STOTT, J.R.W. 1997. The message of Timothy \& Titus. Leicester: InterVarsity. (The BST series.)

VAN DER WALT, B.J. 1999. Kultuur, lewensvisie en ontwikkeling. Potchefstroom: Instituut vir Reformatoriese Studie.

VAN NIEKERK, A.S. 1994. Response to Prof. Beukes' paper. (In Beukes, E., ed. Development in Africa. Potchefstroom: IRS.

VAN ROOY, J.A. 1994. God's selfrevelation and African concepts of God. In die Skriflig, 28(2):261-274.

WELLS, D.F. 1994. God in the wasteland: the reality of truth in a world of fading dreams. Grand Rapids: Eerdmans. 
WINTER, R.D. 2003. What's wrong with 4,000 pastoral training schools worldwide? Mission frontiers, 1:10-11, Mar.-Apr.

WOODS, E., ed. 1995. Education that transforms. Bangalore: Theological Book Trust.ZEMEK, G.J. 1993. The modeling of ministers. Master's seminary journal, 4(4):170-185. (Master's Seminary.)

\section{Kernbegrippe:}

indiensopleiding

karaktervorming

man van God

mentorskap

predikantsopleiding

\section{Key concepts:}

character formation

in service training

man of God

mentoring

training of pastors 